\title{
Faith-Based Medical Neglect: for Providers and Policymakers
}

\author{
Rita Swan ${ }^{1}$
}

Accepted: 19 July 2020 / Published online: 9 October 2020

(C) Springer Nature Switzerland AG 2020

\begin{abstract}
A substantial minority of Americans have religious beliefs against one or more medical treatments. Some groups promote exclusive reliance on prayer and ritual for healing nearly all diseases. Jehovah's Witnesses oppose blood transfusions. Hundreds of thousands of schoolchildren have religious or conscientious exemptions from immunizations. Such exemptions have led to personal medical risk, decreases in herd immunity, and outbreaks of preventable disease. Though First Amendment protections for religious freedom do not include a right to neglect a child, many states have enacted laws allowing religious objectors to withhold preventive, screening, and, in some states, therapeutic medical care from children. Religious exemptions from child health and safety laws should be repealed so that children have equal rights to medical care.
\end{abstract}

Keywords Faith-based medical neglect $\cdot$ Public policy $\cdot$ Religious beliefs

Religion and science are arguably two of the most powerful drivers in human existence. Many consider them different types of truth and both valid while others try to combine them or reject one for the other. Faith-based rejection of medical care has cost the lives of many children and poses challenges to providers.

Asser and Swan (1998) reviewed deaths of 172 U.S. children after medical care was withheld on religious grounds from 1975 to 1995 . Many of the children died of readily treatable infectious diseases and diabetes. The authors found that $80 \%$ of the children would have had at least a $90 \%$ likelihood of survival with timely medical care.

Many types of child abuse and maltreatment have been justified by some on religious grounds - for example, severe corporal punishment, exorcism, forced labor, forced marriage, dangerous diets, conversion therapy, and sexual abuse. Yet only faith-based medical neglect is protected in statute. Preventive and screening measures from which many state laws provide religious exemptions include immunizations, metabolic testing,

Rita Swan is a child advocate. Since 1977 Rita has been working to protect children from harmful religious and cultural practices, especially faith-based medical neglect. She founded the organization Children's Healthcare Is a Legal Duty, Inc. (aka CHILD) and served as its president from 1983 to 2017 .

Rita Swan

rita@childrenshealthcare.org

1 Children's Healthcare Is a Legal Duty Inc (CHILD), 136 Blue Heron Place, Lexington, KY 40,511, USA blood lead-level tests, newborn hearing tests, prophylactic eye drops, vitamin $\mathrm{K}$ injections or drops, vision examinations, dental examinations, and school instruction about disease (Children's Healthcare Is a Legal Duty, hereafter cited in text as CHILD (2020a), Religious exemptions from health care). Oregon and Pennsylvania have religious exemptions from bicycle helmets for children (Pennsylvania Consolidated Statutes \$75-3510(b)(3); Oregon Revised Statutes 814.487).

This article discusses public policy and case law on faithbased medical neglect, beliefs against medical care in several denominations, and advice for providers who encounter religious objectors.

\section{Scope of Statutory Exemptions}

Religious exemptions about medical care of sick and injured children vary widely in meaning. Some are likely innocuous while others allow preventable deaths. Several states have a religious exemption in their reporting laws or in statutory definitions of child abuse and neglect (e.g. Calif. Penal Code $\$ 11,165.2$ (b) and Rev. Code of Washington 26.44.020(18)). Such placement sends a message to the would-be reporter that withholding medical care on religious grounds is not child neglect and therefore should not be reported to state child protection services.

Thirty states have religious defenses in their criminal codes. Nine have religious defenses to negligent homicide, manslaughter, or capital murder. West Virginia's statute defining the crime of murder of a child does "not apply to any 
parent.. . who fails or refuses.. . to supply a child.. . with necessary medical care" on religious grounds" (WV Code 61.8D-2(d)). Arkansas has a religious defense to capital murder for those who cause deaths of children "under circumstances manifesting extreme indifference to human life" (Ark. Code 5-10-101(a)(9)(B)). There could be identical facts on what two Arkansas parents did to a child and one parent could be sentenced to death while the other would not be charged with murder - based upon their different religious beliefs. Virginia has a religious defense allowing Christian Scientists to deprive a child of medical care after they have physically assaulted and injured the child (Va. Code 18-2314).

None of these exemption laws is required by the U.S. Constitution's protections for religious freedom. Rulings upholding the state's right to require medical care of sick children regardless of parents' religious beliefs go back to 1903 (People v. Pierson 1903). In 1944, the U.S. Supreme Court held that the First Amendment does not include a right to neglect a child's health or safety (Prince v. Massachusetts 1944). Many convictions of religious objectors have been upheld on appeal (e.g. Oregon v. Hickman 2015).

In Douglas County v. Anaya (2005), the Nebraska Supreme Court upheld the state's right to require metabolic screening without a religious exemption. In Workman v. Mingo County Schools (2009), relying on many longstanding precedents in case law, a federal appeals court upheld the state's right to require immunizations without a religious exemption.

At the time of this article, no U.S. court has held that parents have a constitutional right to religious practices that abuse or neglect children. States clearly have authority under the Constitution to require parents to provide medical care regardless of their religious beliefs. What remains unsettled, however, is whether legislatures may give parents a statutory right to withhold necessary medical care on religious grounds. At this time, there has been no Supreme Court decision in this regard. A law that allows some parents to deprive their children of medical care while requiring other parents to provide it would seem to violate the rights of children to the equal protection of the laws guaranteed in the fourteenth amendment of the Constitution.

While courts have upheld the state's right to require parents to provide medical care, the federal courts have never ruled on whether children have equal protection rights to medical care (and therefore all parents must be required to provide it). Since parents must give permission for a child to sue and the religious exemptions are a privilege for the same parents whose children are endangered by the exemptions, it is extremely difficult to get courts to rule on this issue.

If the United States ratified the U.N. Convention on the Rights of the Child, children would arguably have rights to medical care, but the U.S. remains the only country in the world not to ratify the convention. Lobbying in state legislatures appears to be the only way to remove religious exemptions. The American Medical Association (1986), American Academy of Pediatrics (2013), National District Attorneys Association (2015), National Association of Medical Examiners (personal communication March 4, 2001), Prevent Child Abuse America (2007), and CHILD (2015) are among the organizations calling for repeal of these religious exemptions. Many religious exemptions are arguably in violation of the Establishment Clause in extending only to adherents of a "well-recognized religion" or "a bona fide" religion. Several courts have ruled that the government cannot give privileges to some sects and not others (Davis v. State 1982; McCarthy v. Boozman 2002; Dalli v. Board of Education 1971 et al.).

\section{Idaho, a Special Case}

The most compelling need for statutory change is in Idaho. The state not only has religious exemptions to manslaughter, non-support, criminal injury, and neglect (Ida. Code 181501(4), 18-401(2), 16-1602(25)(a)) but also has several congregations of denominations that oppose medical care and rely exclusively on prayer and ritual when their children are sick or injured. Idaho began keeping records on stillbirths in 2002 (Ida. Bureau of Vital Records 2015). In Peaceful Valley Cemetery, a cemetery used and controlled by the anti-medical sect Followers of Christ, 33\% (63) of the 189 graves of those dying from 2002 through 2017 are minor children or stillbirths (CHILD, 2020b, Child abuse in Idaho). Statewide only $3 \%$ of Idaho deaths were minor children or stillbirths during those years (Idaho Bureau of Vital Records, 2015 and 2018). Therefore, the proportion of Peaceful Valley graves for minor children and stillbirths is more than 10 times the proportion of deaths among minor children and stillbirths statewide.

If one knew the causes of death for all the children buried in Peaceful Valley, the data would probably look even more elevated for them. Statewide, accidents are the leading cause of death among Idaho children older than one year, but accidents probably account for only a small fraction of the child deaths in Peaceful Valley.

Idaho public officials have generally been indifferent. The legislature unanimously passed the religious defenses to nonsupport, criminal injury of dependents, and manslaughter within four days after they were introduced. A coroner for Canyon County, Idaho where many of the deaths have occurred said in 2011 that she did not even do autopsies on Followers of Christ children because state law requires autopsies only when a crime is suspected and she and law enforcement agree that Idaho allows parents to withhold lifesaving medical treatment from children on religious grounds (Tilkin 2011). In one case, Idaho law enforcement did not report an 
untreated child trauma victim to state child protective services because of the parents' religious beliefs (Nance 2010).

National and state media coverage of preventable deaths of Idaho children has not motivated the legislature to change the law. A bill (HB458) was introduced in 2014 to limit the religious defense but the House speaker would not allow a committee to hold a hearing on it. Representative Christy Perry, RNampa, whose district has had many deaths of Followers' children, said state law should allow their parents to withhold lifesaving medical care because the Followers believe eternity is more important than earthly life (Gettys 2015). Perry dismissed concerns about the children saying they were mostly coming from out of state (Gettys 2015).

Some of the cases for which coroners' reports are available describe symptoms that must have brought great suffering and terror. Here is a coroner's report on the death of an adolescent girl in 2012:

I was told that approximately 3 days earlier that the deceased and 5 other family members had suddenly started having severe nausea, vomiting and diarrhea. I was told that it was felt that they were suffering from some sort of food poisoning. Within 24 to 36 hours all but the deceased started to feel better. The deceased continued to suffer from the above described symptoms and became weaker over the next several hours until she was unable to attempt to eat or drink. She gradually became more lethargic and slipped into unconsciousness. She remained in this state for 4 to 5 hours and went into cardiac arrest. (Canyon County, Idaho Coroner 2012)

On the autopsy, gastrointestinal hemorrhage and a ruptured esophagus were found.

After a long struggle with chronic osteomyelitis in her pelvic bone, another adolescent girl gradually drowned as her lungs filled with fluid from pneumonia (Payette County, Idaho Coroner 2011). In 2013 a four-day old baby died with a bowel obstruction. His belly was hard and distended; his scrotum sac was swollen to four times normal size. (Canyon County, Idaho Coroner 2013). In Peaceful Valley there are graves of 27 children with the last name of Eells and 33 children with the last name of Shippy. After losing four children, one Followers mother said she had struggled with grief and anger but then became glad they were with God (Duara 2017). Many parents must have seen many children die in their extended families and yet refused to change their beliefs against medical care.

A lobbyist for the Christian Science church testified that the religious exemptions were put in Idaho's criminal code at her church's urging. Like laws in several other states, they use Christian Science code words, such as calling prayer "treatment" (e.g. Ida. Code $§ 18-1501(4))$. Many religious exemptions reward extremism in covering only those who rely on "spiritual means alone" to heal the child (e.g. Ida. Code $\S 18-1501(4))$. If the parent combines spiritual remedies with Gatorade or cool baths or finally calls 911 , then s/he is not relying on spiritual means alone and can be prosecuted for neglect of the child.

The religious defenses to homicide apply only to deaths of children and, in some states, of dependent adults. One wonders whether any legislators would agree to a law that allowed others to recklessly cause their deaths. Yet, Idaho is not the only state in which such laws have been passed with no debate or discussion.

Washington State In 1997 Washington enacted a religious defense to criminal mistreatment and second-degree murder stating that Christian Science "treatment" (i.e. prayer) is "medically necessary health care" for children and dependent adults sick with any disease whatsoever (Rev. Code of Wash. 9A.42.005). This law was not considered by committees, given public hearings or debated on the floor. Instead, it was inserted by a six-person conference committee tasked with reconciling House and Senate bills though it was not in either (Wash. Legislative Archives, personal communication, March, 2011). Child advocates had no way of knowing the provision was being considered.

\section{Religious Groups Opposing Standard Child Medical Care}

Christian Science With a salaried lobbyist in every state, the Christian Science church has nearly singlehandedly won hundreds of religious exemptions from medical care for children. They are of two kinds: religious exemptions from providing medical care for sick and injured children and religious exemptions from preventive and screening measures.

The former were widely adopted by states because of federal policy. With many Christian Scientists in high-level positions in the Nixon administration, the U.S. Department of Health, Education and Welfare (Child Abuse and Neglect Prevention and Treatment Program 1974) began requiring states in its grant program to enact a religious exemption to child neglect. After many widely-publicized deaths of children from faith-based medical neglect and strong opposition from child advocates, the federal government (Child Abuse and Neglect Prevention and Treatment Program 2015) dropped the requirement in 1983. By then, however, every state except Nebraska had a religious exemption pertaining to medical care of sick and injured children.

Christian Science is the best-known religion promoting exclusive reliance on prayer for healing. Founder Mary Baker Eddy set up the religion as an alternative health care system and used terminology from medical care for its components. 
Her spiritual healers are called "practitioners," their prayers "treatments," and those they pray for their "patients." The church also has its own unlicensed nurses. Both the treatments and nursing care are fee-based services. (Eddy 1924, p. 237) directed practitioners to make charges "equal to those of reputable physicians" in their communities.

Christian Science teaches that matter and spirit are opposites. The material world and its concomitant sin, sickness, poverty, war, and death are just illusions. Man is God's perfect spiritual mirror image, never born into matter and never dying (Eddy 1934, p. 468). Additionally, Christian Science holds that disease is caused by $\sin$, fear, or ignorance of God, either of the patient or, in the case of a young child, of the parents. The Christian Science remedy for all disease is convincing yourself that disease is unreal because God did not make it and the child is here and now a spiritual idea rather than a mortal living in a material body (Eddy 1934, p. 411).

The theology opposes medical treatment, screenings, and diagnosis for both children and adults. It opposes hygiene, immunizations, health-promoting diets, chiropractic, vitamins, and "material methods" to relieve pain (Eddy 1934, pp. $389,370,421)$. The church prohibits its healers from giving spiritual treatments to anyone who voluntarily obtains medical care unless the care is for a handful of very specific exceptions that the church founder rationalized as acceptable (Christian Science Board of Directors 1945; Lowen, Letter to fellow practitioners, April 1977).

Many outsiders wonder how its "nurses" could perform any nursing services given such a theology. Indeed, Christian Science nurses have an extremely limited scope of practice. They cannot take a pulse or use a fever thermometer. They cannot do simple non-medical procedures to relieve pain, such as putting heat or ice on an injured area. They have no medical training or even first-aid training and do not work under supervision of state-licensed personnel (U.S. Dept. of Health and Human Services 1983; Giebelhaus 1992, pp. 225-6).

In 1986 Boston-area toddler Robyn Twitchell died of sepsis from a twisted and obstructed bowel after five days of extreme pain and vomiting. During his illness a Christian Science nurse continued to feed him (Shubow 1987).

In 1989 a Minneapolis Christian Science nurse attended to 11-year-old Ian Lundman for five hours as he lay in a diabetic coma. She observed his vomiting, labored breathing, excessive urination, facial spasms, and clenched teeth. Her concept of care was to give him drops of water through a straw and to tie a sandwich bag and washcloth around his scrotum. She did not call for medical help or ask his mother to obtain it (Giebelhaus 1992, pp. 226-227). Later in a wrongful death case she testified that the only thing she had been taught specific to the care of children was how to cut sandwiches in interesting shapes (Giebelhaus 1992, pp. 31-32).

The practical services performed by church nurses are keeping the patient and his environment clean, preparing food (though special diets designed to improve health are prohibited by the theology), helping with mobility, and bandaging wounds. The latter is rationalized on grounds that wounds are unsightly and covering them is just for cosmetic reasons. The nurses also encourage the patients to believe the practitioners' treatments are healing them by reading and singing to the patients (Kohn 1988, pp. 62-63).

Medicare and Medicaid reimburse the Christian Science facilities for these menial nursing services at the same rate as for inpatient care in a medical hospital. The payments have been challenged, but a federal appeals court held that the services were a subset of the care one would receive in a medical hospital and upheld the payments. (CHILD v. DeParle 2001).

The church received provisions in early versions of the federal Patient Protection and Affordable Care Act (HR3200 and S.1679) that would have required carriers to reimburse for prayer, but child advocates and secular humanist organizations got the provisions removed. In the past there were hundreds of insurance companies that would reimburse for the bills sent by Christian Science practitioners. Today very few in the private insurance industry do so but several insurance plans for federal and state employees reimburse the bills for their prayers (Christian Science Church 2020). The Internal Revenue Service recognizes bills for Christian Science prayers as a tax-deductible medical expense (IRS Code Section 213(d)).

These recognitions and reimbursements may bolster the church's claim to have a health care system that should be a legal substitute for medical care of sick children. Florida's child protection laws provide a startling example for they authorize judges to order either medical care or Christian Science treatment for any child in the state (Fla. Stat. 39.01(32)(a)(f), 984.03(37), 985.224(8)).

Pentecostals Several small Pentecostal sects also oppose medical care (Asser and Swan 1998, pp. 627-8). Many believe the crucifixion was a vicarious atonement for disease as well as sin. To heal sickness they "plead the blood," which is a legalistic argument that the crucifixion has already saved them from disease (Hughes 1989). After the member makes this declaration, Christ's enemy, the devil, may make the symptoms worse, but the member should firmly insist that healing is guaranteed and ignore disease symptoms. Other favored rituals are anointing with oil and laying on of hands (Hughes 1989). Many also emphasize that the sick person and his family must forgive their enemies to get a spiritual healing (Hughes 1989, pp. 19-22).

Church of Scientology The Church of Scientology opposes some forms of medical care but claims a biochemical basis for its beliefs, which are mixed with the science fiction written by its founder L. Ron Hubbard (Hubbard 1950). Scientology stridently attacks psychiatry (Citizens Commission on Human 
Rights 2020). The church claims to heal all mental health problems with its dianetics, performed in expensive sessions with "auditors," galvanometers, and accusations before a group (Reactive mind, traumatic memories, 2015).

Scientologists believe babies should have a "silent birth" and not be exposed to any discomfort or language for at least the first week of life. Scientologists refuse to have metabolic testing, immunizations, or any other uncomfortable procedures for babies until they are at least a week old (Spiering v. Heineman 2006). Their dietary beliefs have endangered babies. Hubbard discourages breast feeding because there are few "Guernsey-type mothers" today and recommends infants be fed "barley water" instead. Hubbard calls his formula for barley water "the nearest approach to human milk that can be assembled easily" (Hubbard 1988, p. 138).

Jehovah's Witnesses By far the largest denomination with objections to medical care is the Jehovah's Witnesses with millions of members. They oppose blood transfusions on the basis of verses in both the Old and New Testaments that prohibit eating blood. (Jehovah's Witnesses and blood transfusions 2020) They believe the soul is in the blood, and Christ presented a perfect atonement for the sins of all mankind by shedding his blood (Watchtower 1990). Therefore, blood transfusions "[trample] on the Son of God" (Watchtower 1990, pp. 24-26).

The faith has evolved to make several exceptions to its policy as explained by Raymond Franz (1991) and Osamu Muramoto (2001). The Witnesses' publishing house continued to prohibit fractions derived from red cells, white cells, and platelets until 2000 when it published an anonymous statement that fractions derived from all the primary blood components were acceptable (Watchtower 2000).

In the author's experience testifying to 16 state legislatures and U.S. Senate staff, Jehovah's Witnesses have not been seen or heard from and therefore likely rarely lobby legislatures. On grounds that they are actually citizens of a heavenly kingdom, the faith discourages members from holding public office or even voting. They do, however, vigorously defend their interests in court. They have won several First Amendment rights cases at the U.S. Supreme Court (e.g. West Virginia State Board of Education v. Barnette 1943).

Significantly, the High Court ruled against them in the child labor case Prince v. Massachusetts (1944), with its famous words that "the right to practice religion freely does not include liberty to expose the community or child to communicable disease, or the latter to ill health or death.. .." The case has often been cited in other rulings limiting religious freedom when a child's welfare is at stake.

Some European countries have refused to recognize Jehovah's Witnesses as a religion, thus depriving members of status as conscientious objectors to military service and of other benefits. Some countries have complained that the
Witnesses' prohibition of transfusions violates their human rights charters. Former Witnesses claim that church officials negotiated an agreement with Bulgaria pledging that members were absolutely free to accept transfusions in order to get state recognition as a religion, while still punishing members for accepting transfusions in other countries (Barker 1998).

The Jehovah's Witnesses are not faith healers. They do not claim that God will heal them without transfusions. In some publications they embrace martyrdom praising children and families who go to their death rather than accept transfusions (Watchtower 1990, p. 6 and Watchtower 1994). In others they use statements from medical journals to show that transfusions are overused and that blood substitutes will work just as well as blood products (Watchtower 1990, pp. 7-17).

The Amish The Amish place a high value on the work that everyone is expected to do to sustain the community. They tend to define illness in terms of failure to function in the work role rather than of symptoms per se. They also want to live in a pre-industrial culture and often make use of folk remedies and quackery (Adams and Leverland 1986).

A conservative Amish order in New York rejected openheart surgery for a baby with a congenital heart defect because they claimed stopping the heart during surgery would kill the soul and break the baby's connection to God (Mende 2013; Jacobs 2008). Much more commonplace among Amish orders are their very low vaccination rates and outbreaks of infectious disease. In 2014 Ohio Amish had a measles outbreak of 383 cases (Williams 2015).

The Amish strongly oppose insurance and have been exempted from paying into Social Security and Medicare, though Amish employers must provide those benefits for non-Amish employees (Green 2015). In justification of their belief, the Amish point out that Jesus said to take no thought for one's life and not to make one's future secure with earthly goods. Insurance gives a false sense of security and distracts us from laying up treasures in heaven (1001 Questions and Answers 1992, pp. 153-6). The Amish religion calls upon all believers to help pay a member's medical bills and the Amish have a long tradition of doing so.

This tradition is admirable but can also cause reluctance to burden their community with high medical costs. In 1991 an Amish baby died of a genetic disorder after the Amish community refused to pay for the medical treatment and the parents refused to apply for Medicaid. A doctor and drug company offered to lower the costs substantially, but the Amish still insisted the financial burden on their community would be too great (Drake 1991).

Other Groups Many ethnic and cultural groups believe that disease has a supernatural cause and ritual can heal it. Many rely on shamans to enter the spirit world through trance and mediate the sick person and their community with it. They see 
disease as caused by imbalances between man, nature, and spirit, and by loss of spiritual power. A folk belief among the Hmongs is that disease is caused by angry spirits or by the soul leaving the body (Fadiman 1997).

Such Christian and non-Christian groups believe that disease is caused by moral or spiritual factors rather than biochemical ones and is healed by ritual. For the Christian religious objectors, prayer for physical healing becomes a legalistic argument of affirmation and denial.

\section{Religious Beliefs against Immunizations}

Hundreds of thousands of U.S. schoolchildren have religious or conscientious exemptions from immunizations, and scores of outbreaks of vaccine-preventable disease are tied to these exemptions (CHILD, Some outbreaks, 2020). John Grabenstein (2013) provides comprehensive information about the teachings of world religions on vaccines and immune globulin both in support and opposition. Discussion below is confined to some religious objections claimed in the United States.

Anthroposophy, an occult sect, is promoted at the Waldorf schools in the U.S. and elsewhere. The sect believes that children should not be vaccinated because they will have stronger immune systems if they contract infectious diseases naturally (Allen 2002). Some conservative Catholics refuse consent for immunizations developed with aborted fetal tissue, including those for rabies, hepatitis A, varicella, and rubella. Catholic leaders, however, have encouraged members to obtain those vaccines if there is not an alternative type of vaccines available against those diseases (Furton 1999). Some fundamentalist Catholic and Protestant groups charge that the hepatitis B and the human papilloma virus vaccines encourage promiscuity and denigrate the morals they are teaching their children (Lindenberger 2007). Parents have also claimed that the human body is a sacred temple that should not have foreign substances injected into it (McCarthy v. Boozman 2002; Caviezel v. Great Neck Public Schools 2010).

The faith-healing sects believe that one should trust God instead of vaccinations to prevent disease. Christian Science founder Mary Baker Eddy claimed that viruses and bacteria do not cause disease (Eddy 1924, p. 344). Her church teaches that parents can protect children from disease by daily "metaphysical work" to know that God is the only cause and therefore disease is unreal (Roegge 2005).

The Amish have had many outbreaks of vaccinepreventable disease, including rubeola, rubella, pertussis and polio (Swan 2006). Scholar James Cates says that low vaccination rates among the Amish are due to a religious belief-a fatalistic assumption that the Lord will provide and never gives them more than they can handle. This faith is behind disinterest not only in vaccination but also in warning signs on their slow-moving buggies, lightning rods on their buildings, hardhats at construction sites, and smoke detectors (Williams 2015; Cates 2014).

The Amish also have an ideal of "Gelassenheit," which includes not only yielding to God's will but also expressing humility and avoiding confrontation and manipulation in human affairs (Kraybill et al. 2013, pp. 98ff.). When infectious disease strikes, public officials often see both the Gelassenheit and the fatalistic disinterest in preventive health care: the Amish will be very cooperative with Public Health work to contain an epidemic but are unlikely to return for booster shots or immunizations against other diseases once it is over (Williams 2015).

Scores of vaccine-preventable disease outbreaks have occurred in groups with religious beliefs against immunizations (CHILD, Some outbreaks). The three largest U.S. outbreaks of measles since 1990 began among religious objectors. While the 2014 Amish outbreak (Williams 2015) was confined to 383 cases in the Amish community, a 1994 outbreak of 247 cases spread from a Christian Science youth to seven states, a school and college for Christian Scientists, and the St. Louis public schools ("Outbreak of measles among Christian Science students," 1994). Paul Offit (2015, pp. 92-112) has a riveting day-by-day account of the nation's deadliest measles outbreak since 1990. It began in two Philadelphia denominations opposed to immunizations, Faith Tabernacle and First Century Gospel Church. Six children died among the 486 persons who contracted measles in these churches. In addition, three children died, and 938 persons were infected among non-church members.

\section{Non-Medical Exemptions from Immunizations}

The percentage of schoolchildren with personal belief exemptions from immunizations has risen several fold in recent decades. In Iowa, the number of schoolchildren with religious exemptions from immunizations increased more than $300 \%$ between 1991 and 2012 though total school enrollment declined during that period (Swan 2014). Some of the sixteen states that offer "philosophical" exemptions as well as religious exemptions have seen even steeper increases in exempted children (Thompson et al. 2007).

In 2000 rubeola measles was declared eradicated in the U.S. but there have been hundreds of U.S. measles cases in some years since, and pertussis remains endemic (Centers for Disease Control and Prevention 2020). The economic and personal costs of these diseases have led to a debate of how to reduce the number of personal belief exemptions (Reiss and Weithorn 2015). Some call for making it harder to get the exemption and strongly opposing any bills to enact philosophical exemptions. Proposed strategies include requiring vaccine objectors to write an essay explaining their beliefs, watch videos, go to a licensed provider's office and converse with 
the provider about the risks and benefits of vaccines, or have the exemption form notarized every year. Financial incentives can include charging a fee for the administrative costs of processing exemption forms and higher insurance premiums for unvaccinated children.

California (AB2109), Vermont (S.199), and Washington (HB1015) enacted education requirements for the nonreligious belief objectors in 2011-2012. These brought down exemption rates slightly but all three states continued to have large outbreaks of vaccine-preventable disease. In 2015, California repealed all non-medical exemptions from immunizations (SB277). In 2019, Maine (LD798) and New York (A2371A) repealed all non-medical exemptions. California, Maine, New York, West Virginia, and Mississippi are the only states with no religious exemptions from vaccinations for schoolchildren.

The American Medical Association (2015), American Academy of Pediatrics (2016), and American Association of Family Practitioners (Crawford 2015) adopted policies calling for the repeal of all belief exemptions from immunizations. Bioethicists Lantos et al. (2012) are equally direct in calling for repeal of all non-medical exemptions. Perhaps the other proposals simply to make belief exemptions harder to obtain reflected an assumption that actually repealing those exemptions was impossible. California, however, is often a trendsetter in legislation and its success has inspired others.

Certainly, repealing all personal belief exemptions has advantages. Vaccine opponents in Vermont have considered starting their own church (Ferguson 2015). Many vaccine opponents reportedly join the Universal Life Church, which exists only on the internet, to get religious exemptions for their children.

In the United States, immunization requirements apply only to children enrolled in schools or childcare if biological parents have custody. In general, state laws confine definitions of child abuse and neglect to actual harm or imminent risk of harm. Failure to immunize is not considered neglect in those definitions. In some situations, however, the risk is very high. Public health administrator Kathleen Harriman (personal communication April 11, 2012 and July 8, 2015) reports that some California hepatitis B-positive mothers have refused hepatitis B vaccinations for their newborns even though there is a very high likelihood that, without the vaccine being given quickly, the baby will develop chronic hepatitis. State child protection services have refused to intervene.

\section{Suggestions for Providers}

In the 2010 reauthorization of the federal Child Abuse Prevention and Treatment Act Congress includes this statement: "The problem of child abuse and neglect requires a comprehensive approach that.. . recognizes the diversity of ethnic, cultural, and religious beliefs and traditions that may impact child rearing patterns, while not allowing the differences in those beliefs and traditions to enable abuse or neglect" (S.3817 §2 Findings). Many health care providers have a similar goal of respect and sensitivity to families' diverse belief systems while also protecting children from abuse and neglect. Ideally, with mutual respect, the provider and parents will agree upon medically necessary care for the child. About a dozen physicians who have treated children in families with religious objections to medical care have offered these suggestions in personal communications:

- Be aware that the parents and children are very frightened. They see the doctor not as helper and healer but as a threat to their beliefs and culture. Indeed, they see a different reality than the physician.

- Devotees of spiritual healing do not believe that bacteria, viruses, or chemical deficiencies cause disease. They see disease as a moral issue, as evidence of sin, personal conflicts, or even of demonic possession that can be overcome only by ritual (Redlener and Scott 1979). Contact with a physician may jeopardize the parents' traditional support system. They may feel guilt that they have failed to effectuate a healing through faith alone (Gettig 1987).

- They may deny awareness of the symptoms or trivialize them. This is not necessarily dishonesty because many faith-healing churches require members to believe that God has already healed the child in order to see a healing.

- Decision-making is difficult because of the fatalism and self-abnegation imposed by their theology. They may see themselves as a passive channel for a divine being with no will or even mind of their own. The Holiness Churches, whose members are mainly poor African-Americans, see earthly life as vulnerable to hostile forces beyond their control.

Some have observed that parents appear relieved when the court orders medical care. They are relieved of the onus of violating religious doctrine. That does not mean a physician's first step should be a court order. If time permits, obtaining the parents' voluntary consent for treatment is ideal.

Christian Science teaches that information about disease contaminates a person's thinking and then causes disease (Eddy 1934, pp. 370, 383, 389 et al.). The theology encourages members to avoid such information in popular culture and school. On the other hand, criminal trials of Pentecostal faith-healing devotees suggest that some of them seek information on the internet, guess at a diagnosis from what they read, and procure "natural remedies" (e.g. Mehaffey 2012).

With both groups, physicians should maximize opportunities for the parents to gain accurate knowledge of the child's physical condition and of medical care. They should explain the disease process and diagnosis in detail. They should have 
parents touch a mass or other symptomatic area to persuade parents of the reality of the disease or injury. While some faith-healing groups shun education, others such as the Christian Science church have an upper-middle-class membership that is well-educated except on health and the body. Many members of faith-healing groups will use first-aid measures to stop bleeding and have wounds stitched. While some rationalize these remedies as merely "mechanical," it is a fact that they can see blood, but not germs. Explaining the connection between the visible symptoms and their causes can be very helpful.

Health care providers should place a high value on the parent-child bond and facilitate it both during hospitalization and after the child is discharged. They should invite parents to participate in caring for their child even if the child is in intensive care. Parents should be encouraged to bathe the child, to select attractive clothing for her and put it on, etc. It should almost never be necessary to prohibit parents from being with their children. When the illness needs home monitoring, parents can be taught to do it. Social workers can visit the home. The parents can be required to send videos of their care at home. In Newmark v. Williams (1991), the Delaware Supreme Court refused to allow an order for medical treatment of a toddler with Burkitt's lymphoma. The treating oncologist wanted him placed in a foster home because children require intensive home monitoring during chemotherapy, and she did not think Christian Science parents could provide it. The Court held that taking the boy away from his parents would have caused him severe emotional distress.

Providers should ask parents to explain their religious beliefs. They should find out whether the parents oppose all medical care or if objectionable aspects can be avoided and still treat the child effectively. Questions about theological distinctions provide an opportunity for parents to articulate their faith and may disclose room for compromise. Providers can ask why they approve of one procedure instead of another, if the parents are not put on the defensive.

Many physicians will facilitate healing rituals in the hospital such as reshaping the oxygen tent to resemble a symbol, slaughtering a chicken, or ritual dances by shaman if they can be done without disturbing other patients. If the faith-healing group is also an ethnic one, providers should not expect that other members of the ethnic group practice the same religious beliefs or even empathize with them. Immigrants can assimilate quickly. Third generation Hmongs may have different beliefs about health than first-generation Hmong families.

Talking with hierarchy in the parents' religious sect can be either helpful or harmful. Clergy may see more options and more room for interpretation of doctrine than terrified parents. Talking with the religious leaders shows respect for the parents' faith and may increase the parents' willingness to listen to the physician. Public health departments can often boost immunization rates among the
Amish by eliciting the elders' cooperation and by setting up free clinics so that place and time are very convenient for the Amish. Ohio public health staff found the Amish compliant with quarantine and immunization requests during the outbreak but said few returned for the second dose of measles vaccine (Williams 2015).

Some have argued for a very different approach with Jehovah's Witness patients. They describe the Jehovah's Witness hospital committees and elders who are in the patient's room at all hours as coercion that providers should try to protect the patient from. Dr. Osamu Muramoto says that, in its 2000 policy changes, the denomination allowed a "don't tell" policy. It no longer punishes members for accepting transfusions if the patient does not tell them he has accepted a prohibited blood product. Even if there is a blood bag in the patient's room, the Witness overseers do not need to know whether it is a prohibited product; providers should strenuously try to protect the patient's confidentiality rights.

Physicians should not assume that all Witnesses will have the same objections to transfusions and can encourage the patient's independence by knowing the many changes in Watchtower policy and pointing them out. Muramoto (2001) suggests saying to patients, "The component you now refuse may be considered acceptable in a few years. Are you sure you want to refuse it and die now even if you may not have to do so in the near future?" Muramoto also suggests that the doctor could inform the patient that their church no longer requires them to confess their acceptance of a transfusion and that the hospital will keep their medical care confidential. While some have decried Muramoto's advice as medical paternalism, others have defended it as the physician's duty to preserve life and say it is only paternalism if the physician overrides or ignores the patient's wishes (Gillon 2000).

Parents with religious beliefs against medical care have widely divergent attitudes toward physicians. The Jehovah's Witnesses, of course, do not regard themselves as rejecting medical care but simply directing physicians to practice medicine as they want it practiced. Regardless of the parents' belief system, attitude, communication style, or socioeconomic status, the physician must base decisions on the child's medical needs. Some parents may be hostile and poor communicators; others may be professionals who can communicate well. Some theology may sound more reasonable or comprehensible than others. These factors should not influence the physician's assessment of the child. If parents come across as fanatics or obdurate extremists, providers may argue for more intervention than is medically necessary as in the Newmark $v$. Williams case previously mentioned.

On the other hand, in another pediatric cancer case, the parents agreed to chemotherapy initially but after tests showed the cancer was gone, the child refused a further course of consolidation and maintenance chemotherapy, saying God had given her a vision that $\mathrm{s} / \mathrm{h}$ was healed. Providers 
explained to the family that there was a very high likelihood that the cancer would recur without further chemotherapy and it would be more difficult to treat the second time. Parents said they would support whatever decision the child made and promised to return for medical treatment if the child got sick again. These aspects contributed to the feeling of the bioethics team that the parents were "reasonable," and they recommended that the hospital not seek a court order for treatment. The child later relapsed and died.

Both in court and in "negotiating" with parents, those seeking medical care for a child should not raise points that in essence discriminate among religions. For example, if a church says it does not absolutely prohibit medical care and allows members to make their own decision on it, some authorities have argued that the members do not then have the right to raise a religious objection. This is unfair and will lower the public's and the church members' respect for the state's position. The focus should remain on the child's needs. The state's authority to protect the child from harm supersedes his parents' right to practice religion when those rights come into conflict.

\section{Recommendations}

Providers may be able to obtain parents' voluntary consent for treatment by understanding their beliefs, patiently communicating with families, and allowing diversity that does not prevent effective treatment. If they cannot obtain consent and medical care is necessary to prevent substantial harm, they should seek a court order for care.

Such actions are possible only when a child comes to providers' attention. States should not have laws allowing religious objectors to refuse even to bring a sick child to medical attention. Religious exemptions from child health and safety laws should be repealed. The state has no evidence that prayer and ritual heal disease and no authority to oversee their use. It should therefore require all parents to provide medical attention to a child when reasonable parents would recognize a risk of substantial harm. Neglect laws should be modified to include failure to immunize when it poses a risk to an individual child that is much higher than average.

\section{Conclusion}

Using religion as a justification for medical neglect does not support the interests of children but has been allowed under many existing state laws and practices. This has resulted in harm and death. Repeal of such laws would improve the public health and the health of individual children.

\section{Compliance with Ethical Standards}

Conflict of Interest The author states that there is no conflict of interest.

\section{References}

1001 Questions and answers on the Christian life. (1992). Aylmer: Pathway.

AAP Committee on Bioethics. (2013). Conflicts between religious or spiritual beliefs and pediatric care: Informed refusal, exemptions, and public funding. Pediatrics, 132(5), 962-963. https://doi.org/ 10.1542/peds.2013-2716.

AAP Committee on Practice and Ambulatory Medicine, AAP Committee on Infectious Diseases, AAP Committee on State Government Affairs, AAP Council on School Health, AAP Section on Administration and Practice Management. (2016). Medical versus nonmedical immunization exemptions for childcare and school attendance. Pediatrics, 138(3), e20162145. https://doi.org/10.1542/ peds.2016-2145.

Adams, C. E., \& Leverland, M. B. (1986). The effects of religious beliefs on the health care practices of the Amish. The Nurse Practitioner, 11(3), 58-63, 67. https://doi.org/10.1097/00006205-19860300000008 .

Allen, A. (2002). Bucking the herd. Atlantic Monthly, 40, 42.

American Medical Association. (1986). Religious exemptions in child abuse legislation. Report JJ (I-86).

American Medical Association (2015) Why medical reasons should be the only exemptions from vaccination. Retrieved June 23, 2020 http://www.ama-assn.org/ama/ama-wire/post/medical-reasonsshould-only-exemptions-vaccinations

Asser, S., \& Swan, R. (1998). Child fatalities from religion-motivated medical neglect. Pediatrics, 101, 625-629.

Barker, J. (1998). Bulgaria and blood. Watchman Expositor, 15, 18-20.

Canyon County, Idaho Coroner (2012). Record of decedent Arrian Jade Granden. Case \#0298/N/B/12.

Canyon County, Idaho Coroner (2013). Record of decedent Micah Taylor Eels. Case \#0646/N/B/13.

Cates, J. (2014). Serving the Amish: A cultural guide for professionals. John Hopkins University Press.

Caviezel v. Great Neck Public Schools, 739 F. Supp. 2d 273 (E.D.N.Y. 2010).

Centers for Disease Control and Prevention (1994) Outbreak of measles among Christian Science students-Missouri and Illinois, 1994 (1994, July 1). Mortality and Morbidity Weekly Report, 43(25), 463-5. Retrieved September 30, 2020 from https://www.cdc.gov/ mmwr/preview/mmwrhtml/00031788.htm

Centers for Disease Control and Prevention (2020). Measles outbreaks and Pertussis frequently asked questions. Retrieved September 23, 2020 from https://www.cdc.gov/measles/cases-outbreaks.html\# outbreaks and https://www.cdc.gov/pertussis/about/faqs.html

Child Abuse and Neglect Prevention and Treatment Program, 39 Fed. Reg. 43936 (final rule Dec. 19, 1974 codified at 45 C.F.R. pt. 1340).

Child Abuse and Neglect Prevention and Treatment Program, 48 Fed. Reg. 3699-3700 (final rule Jan. 26, 1985 codified at 45 C.F.R. pt. 1340).

Children's Healthcare Is a Legal Duty, Bostrom, and Petersen v. DeParle and Shalala, 212 F.3d 1084 (Eighth Circuit 2000), cert. denied 121 S.Ct. 1483 (2001).

Children's Healthcare Is a Legal Duty (2015). Some outbreaks of vaccine-preventable disease. Retrieved September 23, 2020 from http:// childrenshealthcare.org/?page_id=200 
Children's Healthcare Is a Legal Duty (2020a). Religious exemptions from health care for children. Retrieved September 23, 2020 from http://childrenshealthcare.org/?page_id=24\#Exemptions

Children's Healthcare Is a Legal Duty (2020b). Child abuse in Idaho: deadly and legal. Retrieved September 23, 2020 from http:// idahochildren.org/articles/worst-in-nation/ and http://idahochildren. org/articles/known

Christian Science Board of Directors. (1945). Concerning use of drugs and medicine. The Christian Science Journal, 63, 469.

Christian Science Church (2020). Insurance and Christian Science. Retrieved September 23, 2020 from https://www.christianscience. com/additionalresources/committee-on-publication/u.s.federaloffice/insurance-and-christian-science

Citizens Commission on Human Rights (2020) The Truth About Psychiatry: CCHR Official Reports. Retrieved June 23, 2020 from http://www.cchr.org/cchr-reports/overview.html

Crawford, C. (2015, October 12). New AAFP policy rejects nonmedical immunization exemptions. American Association of Family Physicians. https://www.aafp.org/news/health-of-the-public/ 20151012vaccineexempt.html

Dalli v. Board of Education, 267 NE 2d 219 (Mass. 1971).

Davis v. State, 451 A.2d 107 (Md. 1982).

Douglas County v. Anaya, 694 NW 2d 601 (Neb. 2005), cert. denied S. Ct. 2005.

Drake, D. (1991, March). Amish boy dies; had rare illness. Philadelphia Inquirer.

Duara, N. (2017, April). An Idaho sheriff's daunting battle to investigate when children of faith-healing sect die. Los Angeles Times.

Eddy, M. (1924). First Church of Christ, Scientist, and miscellany. First Church of Christ, Scientist.

Eddy, M. (1934). Science and health with key to the scriptures. Boston: The Christian Science Publishing Society.

Fadiman, A. (1997). The spirit catches you and you fall down: A Hmong child, her American doctors and the collision of two cultures. Macmillan.

Ferguson, D. (2015). Anti-vaxxers hope to sidestep Vermont immunization laws by starting their own religion. Retrieved June 23, 2020 from http://www.rawstory.com/2015/09/anti-vaxxers-hope-tosidestep-vermont-immunization-laws-by-starting-their-ownreligion/

Franz, R. (1991). In search of Christian freedom. Commentary Press.

Furton, E. (1999). Vaccines originating in abortion. National Catholic Bioethics Center, 24, 3-4.

Gettys, T. (2015). Idaho Republican backs faith-healer parents: 'If I want to let my child be with God, why is that wrong?' Retrieved June 23, 2020 from http://www.rawstory.com/2015/02/idaho-republicanbacks-faith-healer-parents-if-i-want-to-let-my-child-be-with-godwhy-is-that-wrong/

Giebelhaus, Q. (1992). Deposition of Quinna lamb Giebelhaus submitted as plaintiff's exhibit \#80 in Lundman v. McKown, 530 NW 2d 807 (Minn. 1995).

Gillon, R. (2000). Refusal of potentially lifesaving transfusions by Jehovah's Witnesses: Should doctors explain that not all JW's think it's religiously required? Journal of Medical Ethics, 26, 299-301.

Grabenstein, J. (2013). What the world's religions teach, applied to vaccines and immune globulins. Vaccine, 31, 2011-2023.

Green, P. (2015). The Amish - Social Security and Medicare taxes. Retrieved June 23, 2020 from http://agebb.missouri.edu/agtax/ issues/ssandse/amishss.pdf

Hubbard L (1950). Dianetics: The modern science of mental health. Hermitage House.

Hubbard L (1988). The second dynamic. Bridge Publications.

Hughes R (1989). The judge and the faith healer. University Press of America.
Idaho Bureau of Vital Records and Health Statistics (2015 and 2018). Idaho resident stillbirths, Idaho resident child fatalities, Idaho resident deaths 2002-2017 supplied by Bureau to author.

Jacobs A. (2008, Dec. 17). Family awaiting ruling. Watertown Daily Times.

Jehovah's Witnesses and blood transfusions (2020). Retrieved June 23, 2020 from https://en.wikipedia.org/wiki/Jehovah\%27s_Witnesses_ and blood transfusions

Kohn, A. (1988, March). Mind over matter. New England Monthly, 5863, 95-97.

Kraybill, D., Johnson-Weiner, K., \& Nolt, S. (2013). The Amish. Johns Hopkins University Press.

Lantos, J., Jackson, M., \& Harrison, K. (2012). Why we should eliminate personal belief exemptions to vaccine mandates. Journal of Health Politics, Policy and Law, 37, 131-140.

Lindenberger M. (2007). An STD vaccine for all girls? Time.

McCarthy v. Boozman, 212 F. Supp. 2d 945 (Dist. Ct. WD Ark. 2002).

Mehaffey, K. (2012). I'm going home. Father accused in faith-healing case testifies. Wenatchee World.

Mende S. (2013). Amish baby forced to have open-heart surgery over parents' objections. Watertown Daily Times.

Muramoto, O. (2001). Bioethical aspects of the recent changes in the policy of refusal of blood by Jehovah's Witnesses. British Medical Journal, 322, 37-39 Retrieved from http://www.ncbi.nlm.nih.gov/ pmc/articles/PMC1119307/.

Nance, J. (2010). Police called in medical case. Idaho Press-Tribune.

National District Attorneys Association (2015). Exemptions from child abuse prosecution. https://ndaa.org/wp-content/uploads/2-11-2015Religious-Exemptions-to-Child-Neglect.pdf

Newmark v. Williams, 588 A.2d 1108 (Del. 1991).

Offit, P. (2015). Bad faith: When religious belief undermines modern medicine. Basic Books.

Oregon v. Hickman, 358 P.3d 987 (Ore. 2015).

Outbreak of measles among Christian Science students-Missouri and Illinois, 1994 (1994, July 1). Mortality and Morbidity Weekly Report, 43(25), 463-5.

Payette County, Idaho Coroner (2011). Report on decedent Pamela Jade Eells.

People v. Pierson, 68 NE 243 (N.Y. 1903).

Prevent Child Abuse America (2007). Resolution on religious exemptions to child abuse/neglect, Resolution 11.14.02.

Prince v. Massachusetts, 321 U.S. 158 (Mass. 1944).

Reactive mind, traumatic memories and auditing (2015). Retrieved from https://en.wikipedia.org/wiki/Scientology\#Reactive_mind.2C_ traumatic memories.2C and auditing

Redlener, I., \& Scott, C. (1979). Incompatibilities of professional and religious ideology: Problems of medical management and outcome in a case of pediatric meningitis. Social Science and Medicine, 13B, 89-93. Available at 10.1016/0160-7987(79)90002-4.

Reiss, D., \& Weithorn, L. (2015). Responding to the childhood vaccination crisis: Legal frameworks and tools in the context of parental vaccine refusal. Buffalo Law Review, 63, 881-980.

Roegge B. (2005). Safe 'in the secret place.' Christian Science Sentinel, 8-9.

Shubow, L. (1987). Report on inquest relating to the death of Robyn Twitchell. Suffolk County, Massachusetts, District Court, 17, 26 28.

Spiering v. Heineman, 448 F.Supp.2d 1129 (D. Neb. 2006).

Swan, R. (2006). Vaccine-preventable disease among the Amish. CHILD newsletter 2006 \#2. Retrieved June 23, 2020 from www. childrenshealthcare.org/wp-content/uploads/2010/10/2006-02-fnl.pdf

Swan, R. (2014). Letter in Des Moines Register, Feb. 22, 2014, with data from Iowa Dept. of Public Health school audits.

Thompson, J., Tyson, S., Card-Higginson, P., Jacobs, R., Wheeler, J. G., Simpson, P., Bost, J., Ryan, K., \& Salmon, D. (2007). Impact of 
addition of philosophical exemptions on childhood immunization rates. American Journal of Preventive Medicine, 32(3), 194-201.

Tilkin, D. (2011). Man speaks out about child deaths in NW faith-healing church. KATU-TV. Retrieved June 23, 2020 from http://www.katu. com/news/local/122359354.html

U.S. Dept. of Health and Human Services (1983). Letter November 23, 1983 from Carolyn Davis to Congressman Berkley Bedell

Watchtower Bible and Tract Society (1990). How can blood save your life?

Watchtower Bible and Tract Society (1994). Youths who put God first. Awake!, May 22, 1994.

Watchtower Bible and Tract Society (2000). Questions from readers. Watchtower, June 15, 2000.
West Virginia State Board of Education v. Barnette, 319 U.S. 624 (WV 1943).

Williams, K. (2015) Amish country's forgotten measles outbreak. Retrieved June 23, 2020 from america.aljazeera.com/articles/2015/ 2/18/amish-countrys-forgotten-measles-outbreak.html.

Workman v. Mingo County Schools, 667 F. Supp. 2d 679 ( $2^{\text {nd }}$ Dist. WV 2009), cert. denied S. Ct. 2011.

Publisher's Note Springer Nature remains neutral with regard to jurisdictional claims in published maps and institutional affiliations. 